Original paper

\title{
Molecular structure of the arsenate mineral chongite from Jáchymov - a vibrational spectroscopy study
}

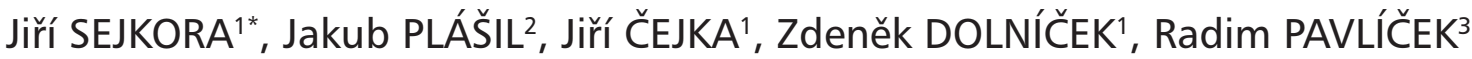 \\ ${ }^{1}$ Department of Mineralogy and Petrology, National Museum, Cirkusová 1740, 19300 Prague 9 - Horní Počernice, Czech \\ Republic;jirisejkora@nm.cz \\ ${ }^{2}$ Institute of Physics ASCR, v.v.i., Na Slovance 1999/2, 18221 Prague 8, Czech Republic \\ ${ }^{3}$ Havličkova 388, Unhošt’ 27351, Czech Republic \\ * Corresponding author
}

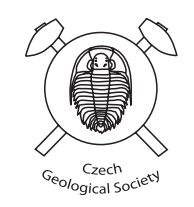

We have undertaken a study of the arsenate mineral chongite from the second world occurrence, which is Jáchymov (Czech Republic). Chongite occurs as colourless to white crystalline spherical and hemispherical aggregates up to $0.3 \mathrm{~mm}$ across composed of rich crusts on strongly weathered fragments of rocks and gangue. The chemical composition of chongite agrees well with the general stoichiometry of the hureaulite group of minerals and corresponds to the following empirical formula: $\mathrm{Ca}_{1.00}\left(\mathrm{Mg}_{124} \mathrm{Ca}_{0.69}{ }_{0.06} \mathrm{Mn}_{0.01}\right)_{\Sigma 2.00} \mathrm{Ca}_{200}\left[\left(\mathrm{AsO}_{3} \mathrm{OH}\right)_{2.13}\left(\mathrm{AsO}_{4}\right)_{1.84}\left(\mathrm{PO}_{4}\right)_{0.03}\right]_{\Sigma 400} \cdot 4 \mathrm{H}_{2} \mathrm{O}$. Chongite is monoclinic, space group $C 2 / c$, with the unit-cell parameters refined from X-ray powder diffraction data: $a 18.618(5)$, $b$ 9.421(2), c 9.988(2) $\AA, \beta$ 96.86(2) ${ }^{\circ}$ and $V$ 1739.4(7) $\AA^{3}$. Raman bands at 3456, 3400, $3194 \mathrm{~cm}^{-1}$ and infrared bands at $3450,3348,3201$ and $3071 \mathrm{~cm}^{-1}$ are assigned to the $v \mathrm{OH}$ stretching structurally distinct differently hydrogen bonded water molecules. Raman bands at $2887,2416 \mathrm{~cm}^{-1}$ and infrared bands at $2904,2783 \mathrm{~cm}^{-1}$ are connected to $v \mathrm{OH}$ stretching in hydrogen bonded $\left(\mathrm{AsO}_{3} \mathrm{OH}\right)^{2-}$ units. Raman bands at $1656,1578 \mathrm{~cm}^{-1}$ and infrared bands at $1652,1601 \mathrm{~cm}^{-1}$ are assigned to the $v_{2}(\delta) \mathrm{H}_{2} \mathrm{O}$ bending vibrations of structurally distinct hydrogen bonded water molecules bonded in the structure by H-bonds of various strength. A Raman band at $1284 \mathrm{~cm}^{-1}$ and infrared bands at 1091 and $1061 \mathrm{~cm}^{-1}$ may be connected to the $\delta$ As- $\mathrm{OH}$ bending vibrations. The most prominent Raman bands at 902, 861, 828, 807, 758 $\mathrm{cm}^{-1}$ and infrared bands at $932,899,863,815,746 \mathrm{~cm}^{-1}$ are attributed to overlapping $v_{1}\left(\mathrm{AsO}_{4}\right)^{3-}$ symmetric stretching, $v_{3}\left(\mathrm{AsO}_{4}\right)^{3-}$ antisymmetric stretching, $v_{1}\left(\mathrm{AsO}_{3} \mathrm{OH}\right)^{2-}$ symmetric stretching, and $v_{3}\left(\mathrm{AsO}_{3} \mathrm{OH}\right)^{2-}$ antisymmetric stretching vibrations. Raman band at $693 \mathrm{~cm}^{-1}$ and infrared bands at 721, $634 \mathrm{~cm}^{-1}$ are assigned to $\delta \mathrm{AsOH}$ bend and molecular water libration modes. Raman bands 506, 469, 451, $436 \mathrm{~cm}^{-1}$ and infrared bands at 503, 466 and $417 \mathrm{~cm}^{-1}$ are connected with the $v_{4}(\delta)\left(\mathrm{AsO}_{4}\right)^{3-}$ and $\left(\mathrm{HOAsO}_{3}\right)^{2-}$ bending vibrations. Raman bands at $389,360,346$ and $302 \mathrm{~cm}^{-1}$ are related to the $v_{2}(\delta)\left(\mathrm{AsO}_{4}\right)^{3-}$ and $\left(\mathrm{HOAsO}_{3}\right)^{2-}$ bending vibrations. Raman bands at 275 and $238 \mathrm{~cm}^{-1}$ are assigned to the $v(\mathrm{OH} \cdots \mathrm{O})$ stretching vibrations and those at $190,162,110,100$ and $75 \mathrm{~cm}^{-1}$ to lattice modes.

Keywords: chongite, hureaulite group, unit-cell parameters, chemical composition, Raman and infrared spectroscopy, Jáchymov ore district

Received: 14 May 2019; accepted: 17 November 2019; handling editor: R. Skála

\section{Introduction}

Hureaulite group minerals comprise monoclinic arsenates and phosphates of generalized composition $M 1 M 2_{2} M_{2}\left(T 1 \mathrm{O}_{4}\right)_{2}\left(T 2 \mathrm{O}_{3} \mathrm{OH}\right)_{2} \cdot 4 \mathrm{H}_{2} \mathrm{O}$ (Tab. 1). The $M 1$ site (Fig. 1) is occupied mainly by $\mathrm{Ca}^{2+}, \mathrm{Mn}^{2+}$ or $\mathrm{Cd}^{2+}$; the $\mathrm{M} 2$ is the preferred site for the smallest octahedrally coordinated cations, as $\mathrm{Mg}^{2+}, \mathrm{Mn}^{2+}, \mathrm{Ca}^{2+}$ or $\mathrm{Zn}^{2+}$. According to Kampf (2009), vacancy may also occur at this site. The $M 3$ site is then occupied by larger cations as $\mathrm{Ca}^{2+}, \mathrm{Mn}^{2+}$ or $\mathrm{Zn}^{2+}$ (Elliot et al. 2009; Kampf 2009; Kampf et al. 2016; Meisser et al. 2019). Arsenate members of this mineral group have the tetrahedrally coordinated $T 1$ and $T 2$ sites occupied by $\left(\mathrm{AsO}_{4}\right)^{3-}$ and $\left(\mathrm{AsO}_{3} \mathrm{OH}\right)^{2-}$ groups with only minor documented contents of the phosphate component.

Chongite, the $\mathrm{Ca}-\mathrm{Mg}-\mathrm{Ca}-\mathrm{As}$ dominant member of the hureaulite group, has been described recently by Kampf et al. (2016) as a new mineral from the Torrecillas mine, Iquique Province, Chile. An unnamed mineral phase "Mg-villyaellenite", described from Jáchymov (Czech Republic) by Ondruš et al. (1997b), is most probably identical with chongite (Kampf et al. 2016).

Although the description of chongite and refinement of its crystal structure has been published recently (Kampf et al. 2016), vibrational (Raman and infrared) spectroscopic studies have not been undertaken so far. Moreover, Raman spectroscopy has been proven as an excellent technique for the study of molecular structure of minerals containing complex oxyanions (e.g., Čejka et al. 2009; Jirásek et al. 2017; Dufresne et al. 2018). Therefore, we have undertaken a vibrational spectroscopy study of chongite, recently found at the second locality in the world, Jáchymov. This paper aims to summarize results of the complex mineralogical study of this arsenate mineral. 
Tab. 1 Ideal occupation of crystal-structure sites of hureaulite group minerals

\begin{tabular}{|c|c|c|c|c|c|c|}
\hline & $M 1(1$ apfu $)$ & $M 2(2$ apfu $)$ & M3 (2 apfu) & $T 1$ & $T 2$ & structure reference \\
\hline hureaulite & $\mathrm{Mn}$ & $\mathrm{Mn}$ & $\mathrm{Mn}$ & $\mathrm{P}$ & $\mathrm{P}$ & Moore and Arakai (1973) \\
\hline miguelromeroite & $\mathrm{Mn}$ & $\mathrm{Mn}$ & $\mathrm{Mn}$ & As & As & Kampf (2009) \\
\hline villyaellenite & $\mathrm{Mn}$ & Mn & $\mathrm{Ca}$ & As & As & Kampf (2009) \\
\hline sainfeldite & $\mathrm{Ca}$ & $\mathrm{Ca}$ & $\mathrm{Ca}$ & As & As & Ferraris and Abbona (1972) \\
\hline chongite & $\mathrm{Ca}$ & $\mathrm{Mg}$ & $\mathrm{Ca}$ & As & As & Kampf et al. (2016) \\
\hline giftgrubeite & $\mathrm{Ca}$ & $\mathrm{Mn}$ & $\mathrm{Ca}$ & As & As & Meisser et al. (2019) \\
\hline
\end{tabular}

$M 1, M 2, M 3, T 1$ and $T 2$ - sites of general formula of hureaulite group minerals $M 1 M 2_{2} M 3_{2}\left(T 1 \mathrm{O}_{4}\right)_{2}\left[\left(T 2 \mathrm{O}_{3}(\mathrm{OH})\right]_{2} \cdot 4 \mathrm{H}_{2} \mathrm{O}\right.$

\section{Material and methods}

\subsection{Occurrence and specimen description}

Chongite was found on several specimens originating from the Jáchymov ore district (formerly St. Joachimsthal), Krušné hory (Erzgebirge) Mountains, approximately $20 \mathrm{~km}$ north of Karlovy Vary (Carlsbad), northwestern Bohemia, Czech Republic. Material originates from the Geschieber vein at the $2^{\text {nd }}$ level of the Svornost mine located in the central part of this ore district (finds were made in April and October 2018).

The Jáchymov ore district is a classic example of $\mathrm{Ag}+$ $\mathrm{As}+\mathrm{Co}+\mathrm{Ni}+\mathrm{Bi}$ and $\mathrm{U}$ vein-type hydrothermal mineralization. The ore veins cut a complex of medium-grade metasedimentary rocks of Cambrian to Ordovician age, in the envelope of a Variscan Karlovy Vary granite pluton (Ondruš et al. 2003a). The majority of the ore minerals were deposited during Variscan mineralization from mesothermal fluids (Ondruš et al. 2003a, b, c). Primary and supergene mineralization in this district resulted in extraordinarily varied associations; more than 440 mineral species have been reported from there up till now (Ondruš et al. 1997a, b, 2003c, d; Hloušek et al. 2014).

Chongite forms rich crusts composed of hemispherical crystalline aggregates having up to $0.3 \mathrm{~mm}$ across (Fig. 2); locally were observed also isolated spherical crystalline aggregates up to $0.2 \mathrm{~mm}$ (Fig. 3) on strongly weathered fragments of rocks and gangue. Chongite aggregates are colourless to white (some with slight yellow or pink tints), translucent, with vitreous lustre and white streak. It is brittle without visible cleavage and has a conchoidal fracture. Chongite is a supergene mineral formed by alteration of As-bearing hypogene minerals (namely native As and nickelskutterudite) in post-mining conditions of an abandoned mining adit.

\subsection{Electron-probe microanalysis}

Samples of chongite were analysed with a Cameca SX-100 electron microprobe (National Museum, Prague) operated in the wavelength-dispersive mode with an accelerating voltage of $15 \mathrm{kV}$, a specimen current of $5 \mathrm{nA}$, and a beam diameter of 10-20 $\mu \mathrm{m}$. The following lines and standards were used: $K_{\alpha}$ : diopside $(\mathrm{Mg})$, rhodonite $(\mathrm{Mn})$, fluorapatite $(\mathrm{Ca}, \mathrm{P}) ; L_{\alpha}:$ clinoclase (As). Peak counting times (CT) were $20 \mathrm{~s}$ for main elements and $60 \mathrm{~s}$ for minor elements; CT for each background was one-half of the peak counting time. The raw intensities were converted to the concentrations automatically

Fig. 1 The crystal structure of As-bearing members of hurealite group of minerals viewed down c. The $\mathrm{As}^{5+}-$ -tetrahedra are green, the $M 1$ site can be occupied by $\mathrm{Mn}, \mathrm{Ca}$ or $\mathrm{Cd}$, the $M 2$ by $\mathrm{Mn}, \mathrm{Mg}, \mathrm{Ca}$, and $\mathrm{Zn}$, the $M 3$ by $\mathrm{Mn}$, $\mathrm{Ca}$ or $\mathrm{Cd}$. The unit-cell edges are shown in solid black lines. For clarity, only a half of the cell content along $\mathrm{c}$ is drawn. 
Fig. 2 Chongite crust formed by hemispherical aggregates, Jáchymov; width of image $1.3 \mathrm{~mm}$.

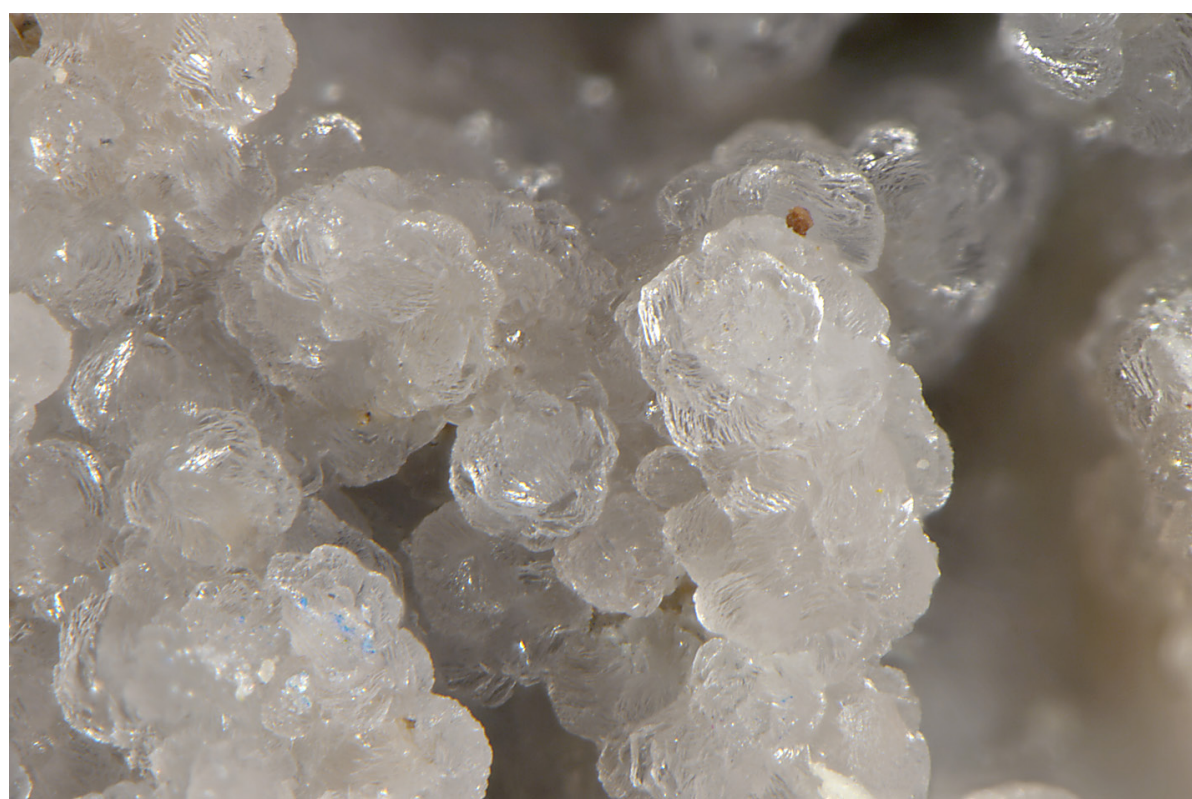

using PAP (Pouchou and Pichoir 1985) matrix-correction software. The elements Al, Co, F, Fe, K, Na, Ni, S, Si and $\mathrm{V}$ were sought (by WDS analysis), but found to be below their respective detection limits (c. $0.05-0.10 \mathrm{wt}$. \%). Water content could not be analysed directly because of the minute amount of material available. The $\mathrm{H}_{2} \mathrm{O}$ content was confirmed by Raman and infrared spectroscopy and calculated by stoichiometry of ideal formula.

\subsection{Powder X-ray diffraction}

Powder X-ray diffraction data were collected on a Bruker D8 Advance diffractometer (National Museum, Prague) with a solid-state 1D LynxEye detector (width $2.05^{\circ}$ ) using $\mathrm{Cu} K$ radiation and operating at $40 \mathrm{kV}$ and $40 \mathrm{~mA}$. The powder patterns were collected using BraggBrentano geometry in the range $3-60^{\circ} 2 \theta$, in $0.01^{\circ}$ steps with a counting time of $30 \mathrm{~s}$ per step. Positions and intensities of reflections were found and refined using the PearsonVII profileshape function with the ZDS program package (Ondruš 1993) and the unit-cell parameters were refined by the least-squares algorithm implemented by Burnham (1962). The experimental pow-

Fig. 3 Spherical crystalline aggregates of chongite on weathered rock, Jáchymov; width of image $0.8 \mathrm{~mm}$. der pattern was indexed in line with the calculated intensities obtained by Lazy Pulverix program (Yvon et al. 1977) from the crystal structure of chongite (Kampf et al. 2016).

\subsection{Raman and infrared spectroscopy}

The Raman spectra of studied sample were collected in the range $4000-50 \mathrm{~cm}^{-1}$ using a DXR dispersive Raman Spectrometer (Thermo Scientific) mounted on a confocal Olympus microscope. The Raman signal was excited by an unpolarised $633 \mathrm{~nm} \mathrm{He}-\mathrm{Ne}$ gas laser and detected by a CCD detector $($ size $1650 \times 200 \mathrm{~mm}$, Peltier cooled

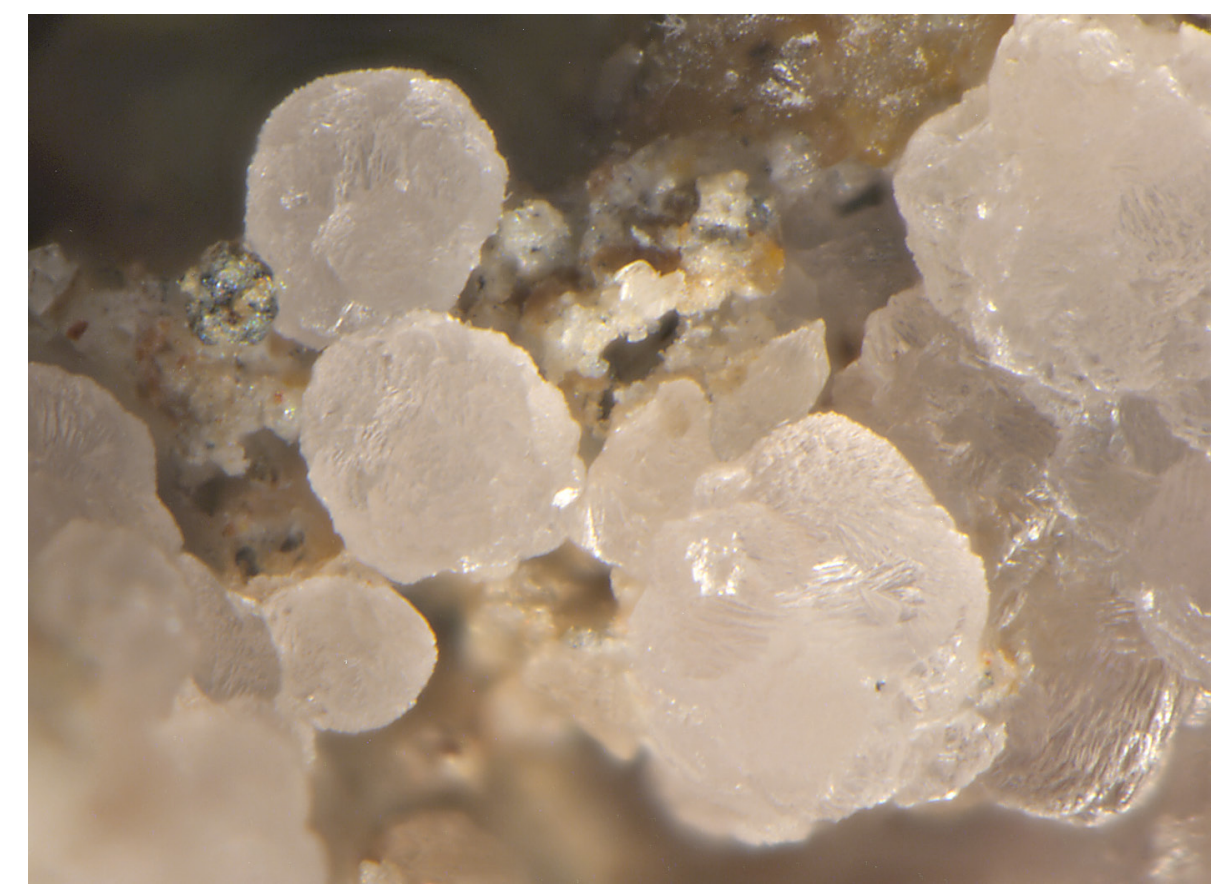


to $-60{ }^{\circ} \mathrm{C}$, quantum efficiency $50 \%$ and dynamic range 360-1100 nm). The experimental parameters were: $100 \times$ objective, $60 \mathrm{~s}$ exposure time, 100 exposures, $50 \mu \mathrm{m}$ pinhole spectrograph aperture and $8 \mathrm{~mW}$ laser power level (estimated resolution 2.6-4.4 $\mathrm{cm}^{-1}$ ). The spectra were repeatedly acquired from different grains in order to obtain a representative spectrum with the best signal-to-noise ratio. The possible thermal damage of the measured point was excluded by visual inspection of exposed surface after measurement, by observation of possible decay of spectral features in the start of excitation and checking for thermal downshift of Raman lines. The instrument was set up by a software-controlled calibration procedure using multiple neon emission lines (wavelength calibration), multiple polystyrene Raman bands (laser-frequency calibration) and standardized white-light sources (intensity calibration).

The infrared vibrational spectrum of chongite was recorded by the attenuated total reflection (ATR) method with a diamond cell on a Nicolet iS5 spectrometer. Spectra over the $4000-400 \mathrm{~cm}^{-1}$ range were obtained by the co-addition of 64 scans with a resolution $4 \mathrm{~cm}^{-1}$ and a mirror velocity of $0.4747 \mathrm{~cm} / \mathrm{s}$. Spectra were co-added to improve the signal-to-noise ratio.

Spectral manipulations were performed using the Omnic 9 software (Thermo Scientific). Gaussian/Lorentzian (pseudo-Voigt) profile functions of the band-shape were used to obtain decomposed band components of the spectra. The decomposition was based on the minimization of the difference in the observed and calculated profiles until the squared correlation coefficient $\left(r^{2}\right)$ was greater than 0.995 .

\section{Results and discussion}

\subsection{Chemical characterization}

Chemical composition of chongite sample (Tab. 2) agrees well with the general formula of the hureaulite group minerals $M 1 M 2_{2} M 3_{2}\left(T 1 \mathrm{O}_{4}\right)_{2}\left(T 2 \mathrm{O}_{3} \mathrm{OH}\right)_{2} \cdot 4 \mathrm{H}_{2} \mathrm{O}$. The $M 1$ and $M 3$ sites are occupied only by $\mathrm{Ca} ; M 2$ site is dominated by $\mathrm{Mg}(1.10-1.47 \mathrm{apfu})$ accompanied by $\mathrm{Ca}(0.45$ $-0.81 a p f u$ ) and only minor Mn (up to $0.02 a p f u$ ). The results suggest that $M 2$ site is not fully occupied and vacancies are also present there $(0.03-0.09 \mathrm{pfu})$. The tetrahedral $T 1$ and $T 2$ sites are dominated by As and only partly substituted by P (0.01-0.05 apfu). The empirical formula of chongite (mean of 19 analyses) on the basis of $\mathrm{As}+\mathrm{P}=4$ apfu is $\mathrm{Ca}_{1.00}\left(\mathrm{Mg}_{1.24} \mathrm{Ca}_{0.69}{ }_{0.06} \mathrm{Mn}_{0.01}\right)_{\Sigma 2.00} \mathrm{Ca}_{2.00}$ $\left[\left(\mathrm{AsO}_{3} \mathrm{OH}\right)_{2.13}\left(\mathrm{AsO}_{4}\right)_{1.84}\left(\mathrm{PO}_{4}\right)_{0.03}\right]_{\Sigma 4.00} \cdot 4 \mathrm{H}_{2} \mathrm{O}$.

In comparison with the type material (Kampf et al. 2016), chongite from Jáchymov is practically Mnfree and at the $M 2$ site contains significant $\mathrm{Ca}$ besides dominant Mg (Fig. 4). This suggests an existence of possible solid solution between chongite and sainfieldite $\left(\mathrm{Ca}_{5}\left(\mathrm{AsO}_{3} \mathrm{OH}\right)_{2}\left(\mathrm{AsO}_{4}\right)_{2} \cdot 4 \mathrm{H}_{2} \mathrm{O}\right)$.

\subsection{Powder X-ray diffraction (XRD)}

The experimental powder data for chongite given in Tab. 3 agree well with the theoretical pattern calculated from the single-crystal data; experimental intensities are

Tab. 2 Chemical composition of chongite from Jáchymov (wt. \%)

\begin{tabular}{|c|c|c|c|c|c|c|c|c|c|c|c|c|c|c|c|}
\hline & $\mathrm{CaO}$ & $\mathrm{MgO}$ & $\mathrm{MnO}$ & $\mathrm{As}_{2} \mathrm{O}_{5}$ & $\mathrm{P}_{2} \mathrm{O}_{5}$ & $\mathrm{H}_{2} \mathrm{O}^{*}$ & total & $\mathrm{Ca}$ & $\mathrm{Mg}$ & $\mathrm{Mn}$ & $\Sigma M$ & $\mathrm{AsO}_{3} \mathrm{OH}$ & $\mathrm{AsO}_{4}$ & $\mathrm{PO}_{4}$ & $\mathrm{H}_{2} \mathrm{O}$ \\
\hline mean & 25.42 & 6.11 & 0.10 & 56.00 & 0.29 & 11.20 & 99.13 & 3.691 & 1.235 & 0.012 & 4.937 & 2.125 & 1.842 & 0.033 & 4 \\
\hline 1 & 26.05 & 5.44 & 0.15 & 56.10 & 0.12 & 11.22 & 99.08 & 3.793 & 1.102 & 0.017 & 4.913 & 2.175 & 1.811 & 0.014 & 4 \\
\hline 2 & 26.18 & 5.47 & 0.02 & 55.55 & 0.44 & 11.19 & 98.85 & 3.814 & 1.109 & 0.002 & 4.925 & 2.149 & 1.800 & 0.051 & 4 \\
\hline 3 & 26.09 & 5.64 & 0.09 & 55.89 & 0.21 & 11.11 & 99.03 & 3.803 & 1.144 & 0.010 & 4.958 & 2.085 & 1.891 & 0.024 & 4 \\
\hline 4 & 25.86 & 5.69 & 0.12 & 55.86 & 0.26 & 11.18 & 98.97 & 3.766 & 1.153 & 0.014 & 4.933 & 2.134 & 1.837 & 0.030 & 4 \\
\hline 5 & 25.71 & 5.73 & 0.08 & 55.64 & 0.34 & 11.18 & 98.68 & 3.751 & 1.163 & 0.009 & 4.923 & 2.154 & 1.806 & 0.039 & 4 \\
\hline 7 & 25.86 & 5.88 & 0.06 & 56.00 & 0.25 & 11.15 & 99.20 & 3.758 & 1.189 & 0.007 & 4.954 & 2.092 & 1.879 & 0.029 & 4 \\
\hline 8 & 25.74 & 5.88 & 0.19 & 56.00 & 0.21 & 11.13 & 99.15 & 3.745 & 1.190 & 0.022 & 4.957 & 2.086 & 1.890 & 0.024 & 4 \\
\hline 9 & 25.82 & 5.88 & 0.19 & 55.90 & 0.28 & 11.11 & 99.18 & 3.756 & 1.190 & 0.022 & 4.968 & 2.065 & 1.903 & 0.032 & 4 \\
\hline 10 & 25.74 & 5.89 & 0.13 & 55.79 & 0.40 & 11.18 & 99.13 & 3.738 & 1.190 & 0.015 & 4.944 & 2.113 & 1.841 & 0.046 & 4 \\
\hline 11 & 25.32 & 6.14 & 0.10 & 56.03 & 0.30 & 11.25 & 99.14 & 3.672 & 1.239 & 0.011 & 4.923 & 2.154 & 1.811 & 0.034 & 4 \\
\hline 12 & 25.43 & 6.15 & 0.06 & 56.29 & 0.21 & 11.26 & 99.40 & 3.681 & 1.239 & 0.007 & 4.926 & 2.147 & 1.829 & 0.024 & 4 \\
\hline 14 & 25.24 & 6.29 & 0.15 & 55.93 & 0.36 & 11.19 & 99.16 & 3.661 & 1.269 & 0.017 & 4.948 & 2.105 & 1.854 & 0.041 & 4 \\
\hline 15 & 25.18 & 6.32 & 0.00 & 56.15 & 0.27 & 11.26 & 99.18 & 3.647 & 1.274 & 0.000 & 4.921 & 2.157 & 1.812 & 0.031 & 4 \\
\hline 16 & 25.08 & 6.50 & 0.15 & 56.20 & 0.30 & 11.22 & 99.45 & 3.627 & 1.308 & 0.017 & 4.952 & 2.097 & 1.869 & 0.034 & 4 \\
\hline 17 & 24.30 & 6.96 & 0.07 & 56.32 & 0.27 & 11.31 & 99.23 & 3.509 & 1.399 & 0.008 & 4.916 & 2.168 & 1.801 & 0.031 & 4 \\
\hline 18 & 24.35 & 6.99 & 0.00 & 55.81 & 0.36 & 11.15 & 98.66 & 3.539 & 1.414 & 0.000 & 4.953 & 2.094 & 1.865 & 0.041 & 4 \\
\hline 19 & 23.93 & 7.34 & 0.11 & 56.41 & 0.25 & 11.27 & 99.31 & 3.453 & 1.473 & 0.013 & 4.939 & 2.123 & 1.849 & 0.029 & 4 \\
\hline
\end{tabular}

Mean of 19 point analyses; 1-19 individual point analyses; apfu on the basis of As $+\mathrm{P}=4$; $\mathrm{H}_{2} \mathrm{O}^{*}$ contents were calculated on the basis of $\left(\mathrm{AsO}_{3} \mathrm{OH}\right)^{2-}$ contents (charge balance) and $4 \mathrm{H}_{2} \mathrm{O}$ molecules in ideal formula 
partly affected by the preferred orientation as well as by the small amount of material available for the study. The refined unit-cell parameters of chongite (Tab. 3) are close to the data published for this mineral from original locality (Kampf et al. 2016). Similarly, as found Meisser et al. (2019) for Mn-Ca members of this group, an increasing portion of $\mathrm{Ca}^{2+}$ entering the structure of $\mathrm{Mg}-\mathrm{Ca}$ members leads to an increasing of unit-cell volume. Considering their ionic radii (Shannon 1976), the [6]-coordinated $\mathrm{Ca}^{2+}$ is larger $(1.00 \AA)$ than [6]-coordinated $\mathrm{Mg}^{2+}(0.72 \AA)$ or $\mathrm{Mn}^{2+}$ $(0.83 \AA)$.

\subsection{Raman and infrared spectroscopy}

In the asymmetric part of the monoclinic (space group $C 2 / c$, $Z=4$ ) chongite unit cell (Kampf et al. 2016), there are three symmetrically distinct $M$ cations (two $\mathrm{Ca}$ and one $\mathrm{Mg}+\mathrm{Ca}$ ), one $\left(\mathrm{AsO}_{4}\right)^{3-}$ and one $\left(\mathrm{AsO}_{3} \mathrm{OH}\right)^{2-}$ group, and two independent $\mathrm{H}_{2} \mathrm{O}$ molecules. The crystal structure of chongite, as same as other members of hureaulite group (Kampf et al. 2016), is based on an octahedral edge-sharing pentamer formed by $M 1(\mathrm{Ca}), M 2$ $(\mathrm{Mg}+\mathrm{Ca})$ and $M 3(\mathrm{Ca})$ octahedra. Pentamers are linked into a loose framework by sharing corners with octahedra in adjacent pentamers and are further linked via $\mathrm{AsO}_{4}$ and $\mathrm{AsO}_{3} \mathrm{OH}$ tetrahedra (Kampf et al. 2016).

The $\left(\mathrm{AsO}_{4}\right)^{3-}$ anion, the point symmetry $T_{\mathrm{d}}, \Gamma=\mathrm{A}_{1}+\mathrm{E}+2 \mathrm{~F}_{2}$, is characterized by four fundamental modes of vibrations, $v_{1}\left(\mathrm{~A}_{1}\right),\left(\sim 837 \mathrm{~cm}^{-1}\right)$, symmetric stretching vibration, $v_{2}(\mathrm{E})$, $\left(\sim 349 \mathrm{~cm}^{-1}\right)$, doubly degenerate bending vibration, $v_{3}\left(\mathrm{~F}_{2}\right),(\sim 878$ $\mathrm{cm}^{-1}$ ), triply degenerate antisymmetric stretching vibration, and $v_{4}\left(\mathrm{~F}_{2}\right),\left(\sim 463 \mathrm{~cm}^{-1}\right)$ triply degenerate bending vibration. The $v_{1}$ vibration is Raman active, $v_{2}$ $(\delta)$ vibration is also Raman active, and $v_{3}$ and $v_{4}(\delta)$ vibrations are Raman and infrared active (Mielke and Ratajczak 1972;
Drozd et al. 2005; Nakamoto 2009). The $T_{\mathrm{d}}$ symmetry of the free $\left(\mathrm{AsO}_{4}\right)^{3-}$ units is only very rarely preserved e.g. in the structure of minerals because of its strong affinity to protons, hydrate and also complex formation with metal cations. The tetrahedral $\mathrm{AsO}_{4}$ symmetry may be therefore reduced to either $C_{3 \mathrm{v}} / C_{3}, C_{2 \mathrm{v}} / C_{2}$, or $C_{1} / C_{\mathrm{s}}$. This loss of degeneracy may cause splitting of degenerate vibrations of $\left(\mathrm{AsO}_{4}\right)^{3-}$ and the shifting of the As-OH stretching vibrations to different wavenumbers (Myneni et al. 1998).
Tab. 3 Powder X-ray diffraction data and refined unit-cell parameters of chongite from Jáchymov

\begin{tabular}{|c|c|c|c|c|c|c|c|c|c|c|c|}
\hline$I_{o b s .}$ & $d_{o b s .}$ & $d_{\text {calc. }}$ & $h$ & $k$ & $l$ & $I_{o b s .}$ & $d_{o b s .}$ & $d_{\text {calc. }}$ & $h$ & $k$ & $l$ \\
\hline 20.7 & 9.238 & 9.242 & 2 & 0 & 0 & 3.0 & 2.2073 & 2.2099 & 2 & 4 & 1 \\
\hline 18.3 & 8.414 & 8.394 & 1 & 1 & 0 & 4.0 & 2.1913 & 2.1939 & 0 & 2 & 4 \\
\hline 7.2 & 6.596 & 6.585 & 1 & 1 & -1 & 2.1 & 2.1525 & 2.1519 & 3 & 1 & 4 \\
\hline 5.7 & 6.248 & 6.242 & 1 & 1 & 1 & 4.4 & 2.1357 & 2.1377 & 7 & 1 & -3 \\
\hline 13.1 & 4.770 & 4.775 & 3 & 1 & -1 & 6.0 & 2.0950 & 2.0984 & 4 & 4 & 0 \\
\hline 9.6 & 4.709 & 4.710 & 0 & 2 & 0 & 4.6 & 2.0790 & 2.0807 & 3 & 3 & 3 \\
\hline 29.3 & 4.626 & 4.621 & 4 & 0 & 0 & 2.1 & 2.0656 & 2.0684 & 4 & 2 & -4 \\
\hline 53.0 & 4.605 & 4.605 & 2 & 0 & -2 & 4.6 & 2.0249 & 2.0211 & 7 & 3 & 0 \\
\hline 31.4 & 4.397 & 4.399 & 3 & 1 & 1 & 2.2 & 2.0127 & 2.0140 & 5 & 3 & -3 \\
\hline 8.4 & 4.255 & 4.255 & 0 & 2 & 1 & 2.7 & 1.9851 & 1.9882 & 8 & 2 & 1 \\
\hline 15.7 & 4.165 & 4.167 & 2 & 0 & 2 & \multirow{2}{*}{2.7} & \multirow{2}{*}{1.8712} & 1.8711 & 6 & 4 & 0 \\
\hline 7.1 & 3.934 & 3.942 & 2 & 2 & -1 & & & 1.8711 & 5 & 3 & 3 \\
\hline 7.1 & 3.787 & 3.792 & 2 & 2 & 1 & \multirow{2}{*}{5.0} & \multirow{2}{*}{1.8472} & 1.8459 & 1 & 5 & -1 \\
\hline 2.8 & 3.440 & 3.441 & 5 & 1 & 0 & & & 1.8446 & 8 & 2 & 2 \\
\hline \multirow{2}{*}{30.7} & \multirow{2}{*}{3.410} & 3.415 & 0 & 2 & 2 & 5.4 & 1.8175 & 1.8167 & 4 & 4 & -3 \\
\hline & & 3.408 & 3 & 1 & 2 & \multirow{2}{*}{4.8} & \multirow{2}{*}{1.8056} & 1.8075 & 3 & 3 & 4 \\
\hline 100.0 & 3.369 & 3.369 & 5 & 1 & -1 & & & 1.8076 & 5 & 1 & -5 \\
\hline 51.7 & 3.300 & 3.299 & 4 & 2 & 0 & \multirow{3}{*}{2.3} & \multirow{3}{*}{1.8012} & 1.8040 & 10 & 0 & -2 \\
\hline 57.8 & 3.290 & 3.293 & 2 & 2 & -2 & & & 1.8010 & 8 & 0 & -4 \\
\hline 26.5 & 3.214 & 3.213 & 4 & 2 & -1 & & & 1.7991 & 7 & 3 & -3 \\
\hline 49.9 & 3.126 & 3.121 & 2 & 2 & 2 & \multirow{2}{*}{6.8} & \multirow{2}{*}{1.7952} & 1.7926 & 5 & 3 & -4 \\
\hline 6.4 & 3.080 & 3.081 & 6 & 0 & 0 & & & 1.7921 & 3 & 1 & 5 \\
\hline 19.5 & 3.020 & 3.020 & 1 & 1 & 3 & 5.3 & 1.7242 & 1.7228 & 9 & 3 & -1 \\
\hline 8.8 & 2.918 & 2.919 & 3 & 1 & -3 & 2.7 & 1.7193 & 1.7188 & 9 & 3 & 0 \\
\hline 4.5 & 2.861 & 2.861 & 4 & 2 & -2 & 3.8 & 1.7150 & 1.7128 & 3 & 5 & -2 \\
\hline 2.0 & 2.797 & 2.798 & 3 & 3 & 0 & 2.8 & 1.7063 & 1.7075 & 0 & 4 & 4 \\
\hline 2.4 & 2.771 & 2.769 & 6 & 0 & -2 & \multirow{2}{*}{6.4} & \multirow{2}{*}{1.6836} & 1.6847 & 10 & 2 & -2 \\
\hline 4.9 & 2.698 & 2.706 & 0 & 2 & 3 & & & 1.6815 & 6 & 4 & -3 \\
\hline 7.1 & 2.684 & 2.690 & 5 & 1 & 2 & \multirow{2}{*}{6.6} & \multirow{2}{*}{1.6643} & 1.6645 & 10 & 2 & 1 \\
\hline 3.8 & 2.655 & 2.655 & 3 & 3 & 1 & & & 1.6618 & 2 & 0 & -6 \\
\hline 2.9 & 2.554 & 2.558 & 6 & 2 & -1 & 4.8 & 1.6598 & 1.6582 & 7 & 3 & 3 \\
\hline 7.4 & 2.533 & 2.534 & 7 & 1 & -1 & 6.6 & 1.6553 & 1.6551 & 1 & 3 & 5 \\
\hline 7.5 & 2.4793 & 2.4792 & 0 & 0 & 4 & & & 1.6406 & 5 & 5 & 1 \\
\hline 7.4 & 2.4390 & 2.4367 & 6 & 2 & 1 & 2.3 & 1.6396 & 1.6413 & 5 & 1 & 5 \\
\hline 16.3 & 2.3971 & 2.3975 & 7 & 1 & 1 & & & 1.6391 & 1 & 5 & -3 \\
\hline 18.0 & 2.3904 & 2.3934 & 5 & 3 & 0 & 2.2 & 1.6047 & 1.6052 & 1 & 1 & 6 \\
\hline 7.1 & 2.3744 & 2.3762 & 7 & 1 & -2 & 5.3 & 1.5720 & 1.5723 & 10 & 2 & 2 \\
\hline 11.4 & 2.3126 & 2.3105 & 8 & 0 & 0 & 5.4 & 1.5685 & 1.5671 & 2 & 2 & -6 \\
\hline 23.8 & 2.3036 & 2.3023 & 4 & 0 & -4 & 2.0 & 1.5643 & 1.5645 & 5 & 5 & 2 \\
\hline 7.7 & 2.2805 & 2.2825 & 1 & 3 & -3 & 16.3 & 1.5412 & 1.5404 & 12 & 0 & 0 \\
\hline \multirow{2}{*}{4.4} & \multirow{2}{*}{2.2361} & 2.2386 & 2 & 4 & -1 & 7.5 & 1.5358 & 1.5338 & 7 & 5 & 0 \\
\hline & & 2.2374 & 1 & 3 & 3 & & & & & & \\
\hline
\end{tabular}




\section{$\mathrm{Mn}$}

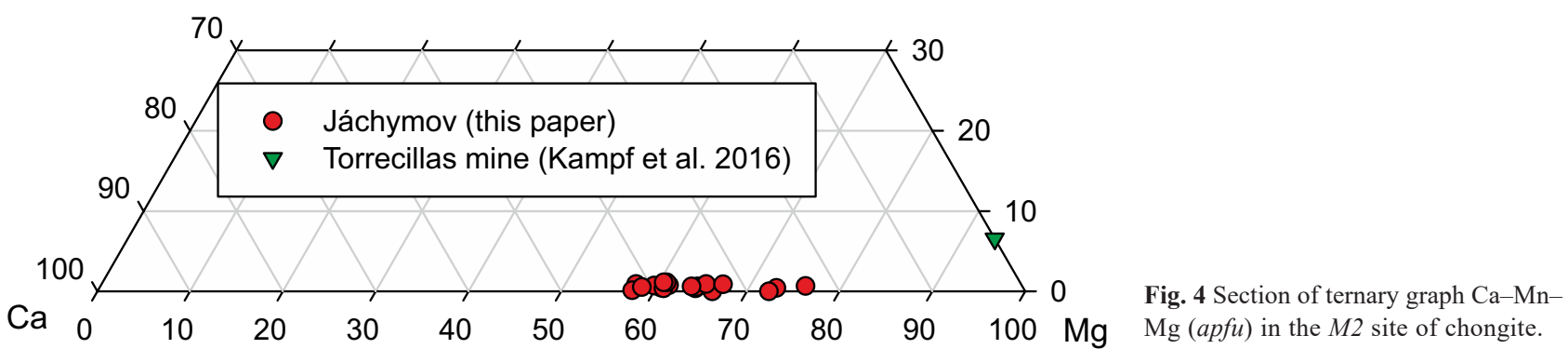

According to Mielke and Ratajczak (1972), $\left(\mathrm{AsO}_{3} \mathrm{OH}\right)^{2-}$ ion belongs to the point group $C_{3 \mathrm{v}}$. For the modes involving arsenic and oxygen, the total representation reduces to $\Gamma=3 A_{1}+3 E$. One should expect in the Raman spectrum six fundamental vibrations; however, only four bands have been observed in the Raman studies of aqueous solution of $\left(\mathrm{AsO}_{3} \mathrm{OH}\right)^{2-}$. The Raman and infrared spectra for some synthetic compounds containing $\left(\mathrm{AsO}_{3} \mathrm{OH}\right)^{2-}$ group were published e.g. by Keller (1971), Vansant et al. (1973), Mihajlović et al. (2004), Drozd et al. (2005), Đorđević and Karanović (2008, 2010), Đorđević et al. (2015, 2018). Raman spectra of
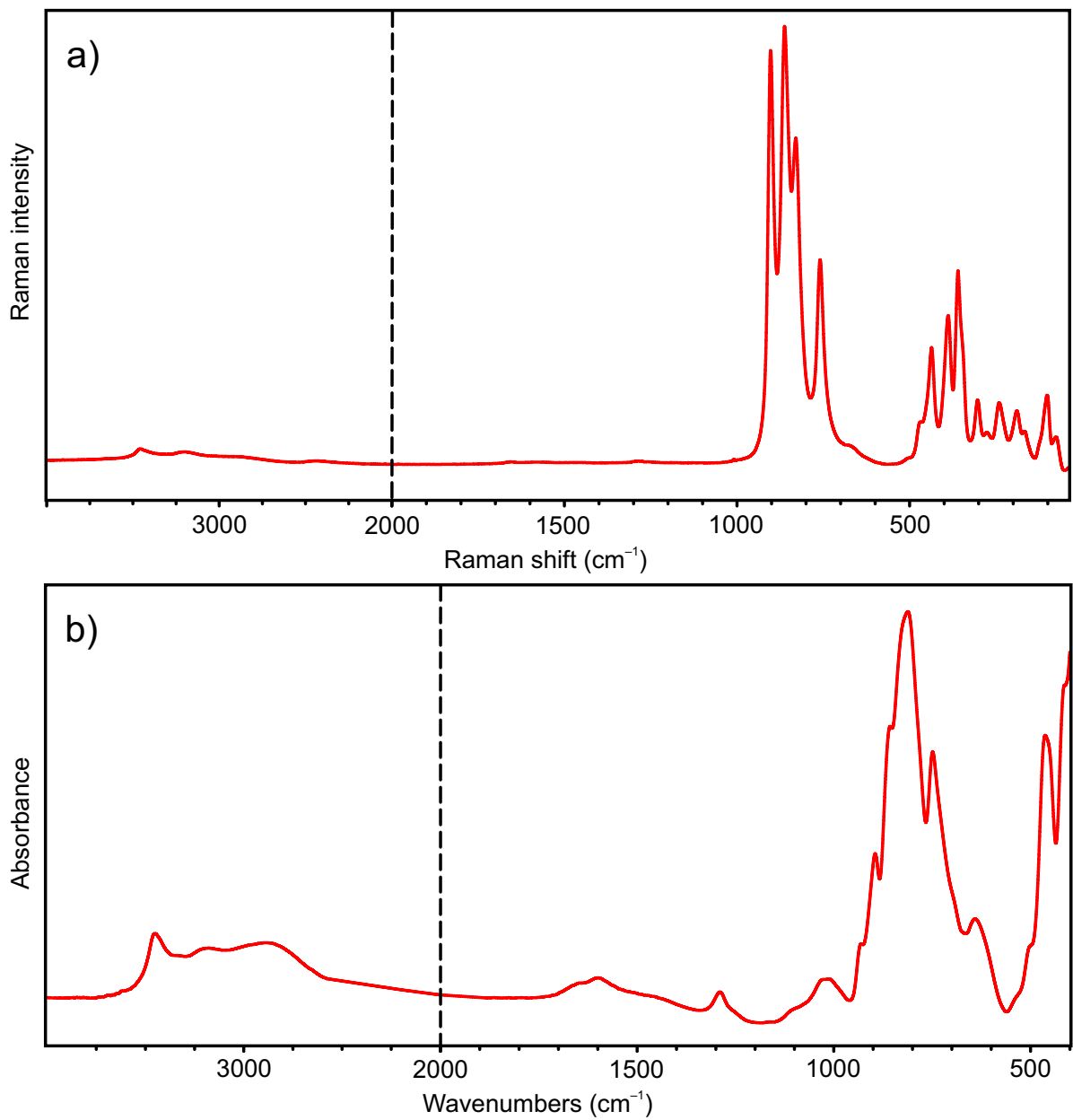

some hydrogen-arsenate ions-containing minerals were studied, e.g. burgessite (Čejka et al. 2011), pharmacolite (Frost et al. 2010), geminite (Sejkora et al. 2010) and giftgrubeite (Meisser et al. 2019). Raman and infrared spectra of štěpite have been interpreted in detail by Plášil et al. (2013). Makreski et al. (2018) presented a paper on vibrational spectra of complex hydrogen-arsenate minerals pharmacolite, picropharmacolite and vladimirite including DFT (Density Functional Theory) calculation of theoretical spectra.

Summarizing these data, as indicated, it is possible to use them generally for tentative interpretation of the Raman spectra of synthetic and mineral compounds containing $\left(\mathrm{AsO}_{3} \mathrm{OH}\right)^{2-}$ units. When comparing published Raman spectra, however, dispersion of observed related wavenumbers of studied spectra may be significant. Raman bands at $\sim 3465-3050 \mathrm{~cm}^{-1}$ are related to the $v \mathrm{OH}$ of hydrogen bonded $\mathrm{OH}$ in $\left(\mathrm{AsO}_{3} \mathrm{OH}\right)^{2-}$ units, bands at $\sim 2250-2325$ $\mathrm{cm}^{-1}$ to the strongly hydrogen bonded $\mathrm{OH}$ in $\left(\mathrm{AsO}_{3} \mathrm{OH}\right)^{2-}$, bands at $\sim 1090-1300 \mathrm{~cm}^{-1}$ to $\delta$ As- $\mathrm{OH}$ vibrations. Raman bands at $\sim 870-958 \mathrm{~cm}^{-1}$ to the $v_{3}\left(\mathrm{AsO}_{3} \mathrm{OH}\right)^{2-}$ antisymmetric stretch, bands at $\sim 846-872 \mathrm{~cm}^{-1}$ to the $v_{1}\left(\mathrm{AsO}_{3} \mathrm{OH}\right)^{2-}$ symmetric stretch, bands at $\sim 825-855$ $\mathrm{cm}^{-1}$ to the $\delta \mathrm{AsOH}$ bend and $v_{1}$ $\left(\mathrm{AsO}_{3} \mathrm{OH}\right)^{2-}$ symmetric stretch vibrations. Raman bands at $700-760 \mathrm{~cm}^{-1}$, and $\sim 434-555$ $\mathrm{cm}^{-1}$ to the As-OH, 435-470

Fig. 5a - Raman spectrum of chongite over the $50-4000 \mathrm{~cm}^{-1}$ spectral range; b - Infrared spectrum of chongite over $400-4000 \mathrm{~cm}^{-1}$; both spectra are split at $2000 \mathrm{~cm}^{-1}$. 
$\mathrm{cm}^{-1}$ to the $v_{4}(\delta)\left(\mathrm{AsO}_{3} \mathrm{OH}\right)^{2-}$ bend, $\sim 370-90 \mathrm{~cm}^{-1}$ to the $v_{2}$

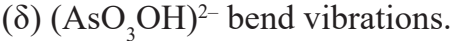
Overlaps and coincidences of some bands are expected.

The full-range Raman and infrared spectra of the studied mineral chongite are given in Fig. 5a-b, tabularized values in Tab. 4. Raman bands of chongite at $3456,3400,3194$, 2887 and $2416 \mathrm{~cm}^{-1}$ (Fig. 6a) and infrared bands at 3450 , 3348, 3201, 3071, 2904 and $2783 \mathrm{~cm}^{-1}$ (Fig. 7a) are assigned to the $v \mathrm{OH}$ stretching vibrations. The bands in the range $3500-3000 \mathrm{~cm}^{-1}$ are connected with vibrations of structurally distinct and differently strong hydrogen-bonded water molecules. According to Libowitzky's empirical relation (Libowitzky 1999) O-H..O hydrogen bond lengths vary approximately in the ranges $\sim 2.85$ to $\sim 2.74 \AA$ (Raman) and $\sim 2.85$ to $\sim 2.67 \AA$ (infrared). These values are comparable to hydrogen bond lengths of water molecules, inferred from the single-crystal structure data (2.99 to $2.71 \AA)$ of chongite (Kampf et al. 2016). The bands in this range may be also related to the $v \mathrm{OH}$ of hydrogen bonded $\mathrm{OH}$ in $\left(\mathrm{AsO}_{3} \mathrm{OH}\right)^{2-}$ units. The bands of the $v \mathrm{OH}$ stretching vibration of $\left(\mathrm{AsO}_{3} \mathrm{OH}\right)^{2-}$ units are assumed at $2900 \mathrm{~cm}^{-1}$ as mentioned by Mielke and Ratajczak (1972), and at 3200, 2800 and $2250 \mathrm{~cm}^{-1}$ as published by Keller (1971). The calculated O-H...O hydrogen bond lengths $\sim 2.63$ to $\sim 2.57 \AA$ (Raman) and $\sim 2.64$ to $\sim 2.61 \AA$ (infrared) for these more strongly bonded $\mathrm{OH}$ units agree with distance $2.638 \AA$ from single-crystal structure data (Kampf et al. 2016).

Raman bands at 1656 and $1578 \mathrm{~cm}^{-1}$ (Fig. 6b) as well as very broad infrared band with the maxima at 1652 and $1601 \mathrm{~cm}^{-1}$ (Fig. 5b) are connected with the $v_{2}(\delta)$ bending vibrations of differently strong hydrogen bonded water molecules. A Raman band at $1462 \mathrm{~cm}^{-1}$ may probably be related to an overtone or a combination band. A Raman band at $1284 \mathrm{~cm}^{-1}$ (Fig. 6b) and two infrared bands at
Tab. 4 Tentative interpretation of Raman and infrared spectra for chongite

\begin{tabular}{|c|c|c|c|c|}
\hline & Raman & & infrared & tentative assignment \\
\hline $\begin{array}{c}\text { position } \\
{\left[\mathrm{cm}^{-1}\right]}\end{array}$ & $\begin{array}{c}F W H M \\
{\left[\mathrm{~cm}^{-1}\right]}\end{array}$ & $I_{\text {rel. }}$ & $\begin{array}{c}\text { position } \\
{\left[\mathrm{cm}^{-1}\right]}\end{array}$ & \\
\hline 3456 & 72 & 5 & 3450 & \multirow{4}{*}{$v \mathrm{OH}$ stretch of hydrogen bonded water molecules } \\
\hline 3400 & 166 & 4 & 3348 & \\
\hline \multirow[t]{2}{*}{3194} & 268 & 24 & 3201 & \\
\hline & & & 3071 & \\
\hline \multirow[t]{2}{*}{2887} & 305 & 6 & 2904 & \\
\hline & & & 2783 & $v \mathrm{OH}$ stretch of hydrogen bonded $\left(\mathrm{AsO}_{3} \mathrm{OH}\right)^{2-}$ \\
\hline 2416 & 164 & 2 & & \\
\hline 1656 & 39 & 1 & 1652 & \multirow{2}{*}{$v_{2}(\delta)$ bend of hydrogen bonded water molecules } \\
\hline 1578 & 110 & 1 & 1601 & \\
\hline 1462 & 101 & 1 & & overtone or combination band \\
\hline \multirow[t]{4}{*}{1284} & 59 & 1 & 1291 & \multirow{3}{*}{$\delta$ As- $-\mathrm{OH}$ bend } \\
\hline & & & 1091 & \\
\hline & & & 1016 & \\
\hline & & & 932 & \multirow{6}{*}{$\begin{array}{l}v_{3}\left(\mathrm{AsO}_{4}\right)^{3-} \text { antisymmetric stretch, } v_{3}\left(\mathrm{AsO}_{3} \mathrm{OH}\right)^{2-} \\
\text { antisymmetric stretch, } v_{1}\left(\mathrm{AsO}_{4}\right)^{3-} \text { symmetric stretch, } \\
v_{1}\left(\mathrm{AsO}_{3} \mathrm{OH}\right)^{2-} \text { symmetric stretch }\end{array}$} \\
\hline 902 & 19 & 46 & 899 & \\
\hline 861 & 30 & 100 & 863 & \\
\hline 828 & 25 & 43 & & \\
\hline 807 & 23 & 5 & 815 & \\
\hline 758 & 24 & 40 & 746 & \\
\hline \multirow[t]{2}{*}{693} & 79 & 7 & 721 & \multirow{2}{*}{$\delta$ As- $-\mathrm{OH}$ bend, molecular water libration modes } \\
\hline & & & 634 & \\
\hline 506 & 18 & 1 & 503 & \multirow{4}{*}{$v_{4}(\delta)\left(\mathrm{AsO}_{4}\right)^{3-}$ bend, $v_{4}(\delta)\left(\mathrm{AsO}_{3} \mathrm{OH}\right)^{2-}$ bend } \\
\hline 469 & 22 & 5 & 466 & \\
\hline 451 & 16 & 3 & & \\
\hline 436 & 19 & 16 & 417 & \\
\hline 389 & 25 & 29 & & \multirow{4}{*}{$v_{2}(\delta)\left(\mathrm{AsO}_{4}\right)^{3-}$ bend, $v_{2}(\delta)\left(\mathrm{AsO}_{3} \mathrm{OH}\right)^{2-}$ bend } \\
\hline 360 & 14 & 12 & & \\
\hline 346 & 18 & 13 & & \\
\hline 302 & 22 & 10 & & \\
\hline 275 & 20 & 3 & & \multirow{2}{*}{$v(\mathrm{OH} \cdots \mathrm{O})$ stretch } \\
\hline 238 & 33 & 15 & & \\
\hline 190 & 29 & 11 & & \multirow{5}{*}{ lattice vibrations } \\
\hline 162 & 24 & 4 & & \\
\hline 110 & 31 & 9 & & \\
\hline 100 & 14 & 5 & & \\
\hline 75 & 19 & 4 & & \\
\hline
\end{tabular}

$I_{\text {rel. }}$ calculated from the band area

1091 and $1061 \mathrm{~cm}^{-1}$ (Fig. 7b) may be connected to the $\delta$ As-OH bend (Plášil et al. 2013).

The most prominent Raman bands at 902, 861, 828, 807 and $758 \mathrm{~cm}^{-1}$ (Fig. 6c) and infrared bands at 932, $899,863,815$ and $746 \mathrm{~cm}^{-1}$ (Fig. $7 \mathrm{~b}$ ) are attributed to overlapping $v_{1}\left(\mathrm{AsO}_{4}\right)^{3-}$ symmetric stretching, split $v_{3}\left(\mathrm{AsO}_{4}\right)^{3-}$ triply degenerate antisymmetric stretching, $v_{1}\left(\mathrm{AsO}_{3} \mathrm{OH}\right)^{2-}$ symmetric stretching, and split $v_{3}$ $\left(\mathrm{AsO}_{3} \mathrm{OH}\right)^{2-}$ triply degenerate antisymmetric stretching vibrations. The bands of the higher wavenumbers can be assigned more favourably to the protonated $\left(\mathrm{AsO}_{3} \mathrm{OH}\right)^{2-}$ group (Makreski et al. 2018), but due to presence of both $\left(\mathrm{AsO}_{4}\right)^{3-}$ and $\left(\mathrm{AsO}_{3} \mathrm{OH}\right)^{2-}$ groups in crystal structure of chongite more detailed tentative assignments would be 

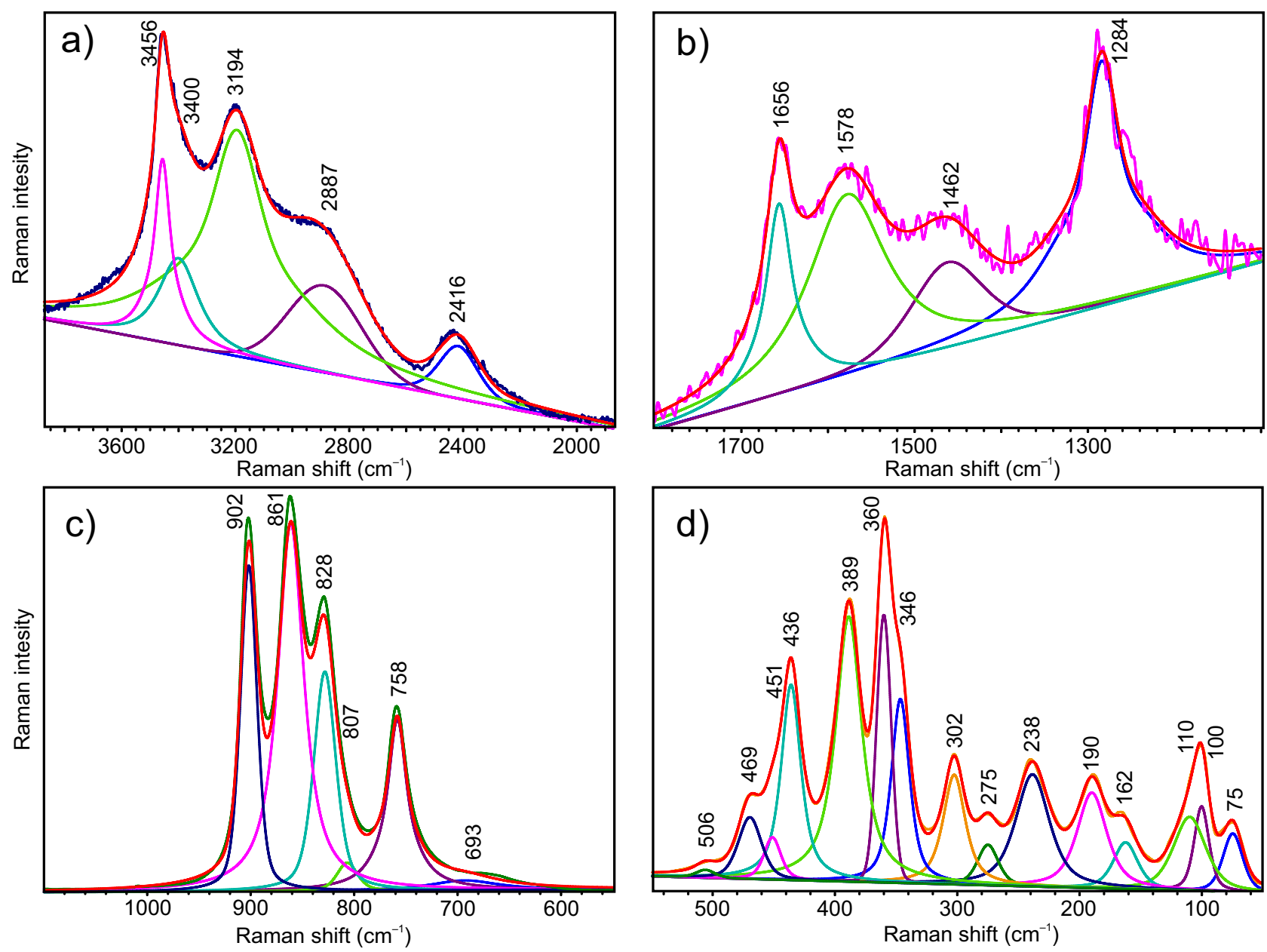

Fig. 6 Results of the band component analysis in the Raman spectrum of chongite.

only speculative. A Raman band at $693 \mathrm{~cm}^{-1}$ and infrared bands at 721 and $634 \mathrm{~cm}^{-1}$ are assigned to $\delta \mathrm{AsOH}$ bend and molecular water libration modes (Yukhnevich 1973; Plášil et al. 2013).

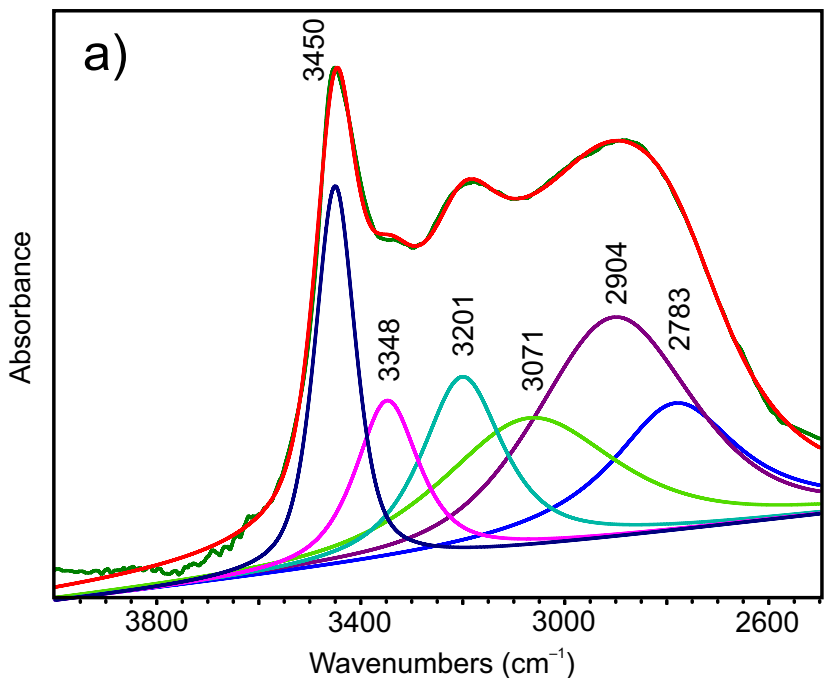

Raman bands in the range from 550 to $400 \mathrm{~cm}^{-1}(506$, 469,451 and $436 \mathrm{~cm}^{-1}-$ Fig. $6 \mathrm{~d}$ ) and infrared bands at 503,466 and $417 \mathrm{~cm}^{-1}$ (Fig. 5b) are connected with the split triply degenerate $v_{4}(\delta)\left(\mathrm{AsO}_{4}\right)^{3-}$ vibrations and

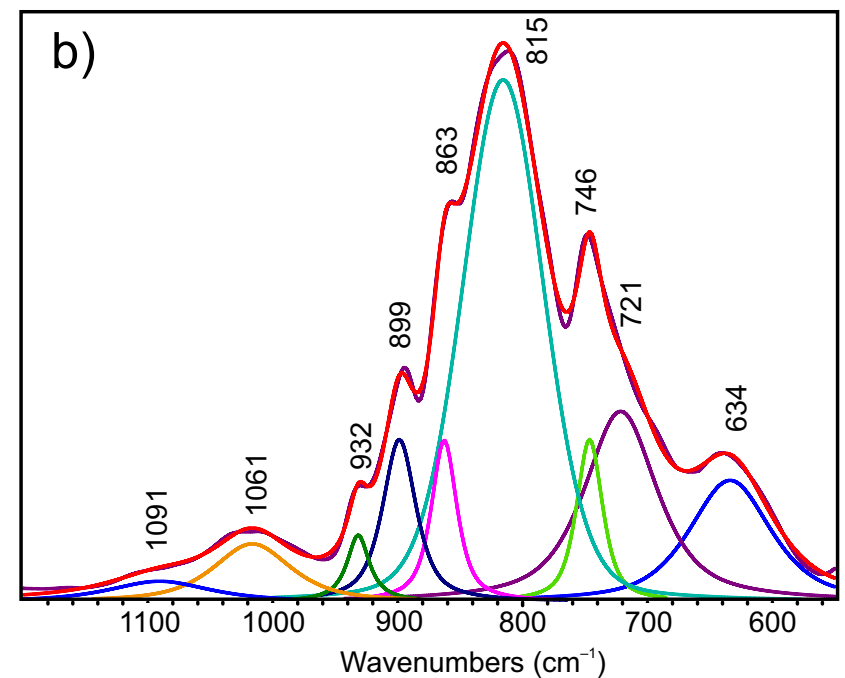

Fig. 7 Results of the band component analysis in the selected area of the infrared spectrum of chongite. 
the split triply degenerate $v_{4}(\delta)\left(\mathrm{HOAsO}_{3}\right)^{2-}$ vibrations (Plášil et al. 2013). Sharp bands of the medium intensity at $389,360,346$ and $302 \mathrm{~cm}^{-1}$ (Fig. 6d) are related to the split doubly degenerate $v_{2}(\delta)\left(\mathrm{AsO}_{4}\right)^{3-}$ vibrations and the split doubly degenerate $v_{2}(\delta)\left(\mathrm{HOAsO}_{3}\right)^{2-}$ vibrations, respectively (Drozd et al. 2005; Čejka et al. 2011; Plášil et al. 2013). Raman bands at 275 and $238 \mathrm{~cm}^{-1}$ (Fig. 6d) are assigned to the $v(\mathrm{OH} \cdots \mathrm{O})$ stretching vibrations and those at 190,162,110, 100 and $75 \mathrm{~cm}^{-1}$ to lattice modes (Plášil et al. 2013).

\section{Conclusions}

Molecular structure of well-defined sample of chongite from Jáchymov (the second world occurrence) was constrained using the vibrational spectroscopy. Raman and infrared spectroscopy shows the presence of both $\left(\mathrm{AsO}_{4}\right)^{3-}$ and $\left(\mathrm{AsO}_{3} \mathrm{OH}\right)^{2-}$ units in the crystal structure of chongite. Multiple bands related to vibrations of water molecules prove the presence of differently strong hydrogen bonded and structurally distinct water molecules in the structure of chongite.

Acknowledgements. An anonymous reviewer and A. Shiryaev, as well as handling editor Roman Skála and editor in chief Vojtěch Janoušek, are highly acknowledged for the comments and suggestions greatly improving the manuscript. The authors wish to express their thanks to Jana Ulmanová (National Museum, Prague) for her kind support in this study. This work was financially supported by Czech Science Foundation (project GAČR 17-09161S).

\section{References}

Burnham CH W (1962) Lattice constant refinement. Carnegie Inst Washington Year Book 61: 132-135

Čejka J, Frost RL, Sejkora J, Keeffe EC (2009) Raman spectroscopic study of the uranyl sulphate mineral jáchymovite $\left(\mathrm{UO}_{2}\right)_{8}\left(\mathrm{SO}_{4}\right)(\mathrm{OH})_{14} \cdot 13 \mathrm{H}_{2} \mathrm{O}$. J Raman Spectrosc 40: 1464-1468

Čejka J, Sejkora J, Bahfenne S, Palmer SJ, Plášsll J, Frost RL (2011) Raman spectroscopy of hydrogen-arsenate group $\left(\mathrm{AsO}_{3} \mathrm{OH}\right)$ in solid-state compounds: cobalt mineral phase burgessite $\mathrm{Co}_{2}\left(\mathrm{H}_{2} \mathrm{O}\right)_{4}\left[\mathrm{AsO}_{3} \mathrm{OH}\right]_{2} \cdot \mathrm{H}_{2} \mathrm{O}$. J Raman Spectrosc 42: 214-218

ĐorĐEVIĆ T, KARANOVIĆ L (2008) Synthesis, crystal structure, infrared and Raman spectra of $\mathrm{Sr}_{4} \mathrm{Cu}_{3}\left(\mathrm{AsO}_{4}\right)_{2}\left(\mathrm{AsO}_{3} \mathrm{OH}\right)_{4} \cdot$ $3 \mathrm{H}_{2} \mathrm{O}$ and $\mathrm{Ba}_{2} \mathrm{Cu}_{4}\left(\mathrm{AsO}_{4}\right)_{2}\left(\mathrm{AsO}_{3} \mathrm{OH}\right)_{3}$. J Solid State Chem 181: 2889-2898

ĐorĐEVIĆ T, KARANOVIĆ L (2010) A new polymorph of $\mathrm{Ba}\left(\mathrm{AsO}_{3} \mathrm{OH}\right)$ : synthesis, crystal structure and vibrational spectra. J Solid State Chem 183: 2835-2844
ĐorĐević T, WitTwer A, Krivovichev SV (2015) Three new alluaudite-like protonated arsenates: $\mathrm{NaMg}_{3}\left(\mathrm{AsO}_{4}\right)$ $\left(\mathrm{AsO}_{3} \mathrm{OH}\right)_{2}, \mathrm{NaZn}_{3}\left(\mathrm{AsO}_{4}\right)\left(\mathrm{AsO}_{3} \mathrm{OH}\right)_{2}$ and $\mathrm{Na}\left(\mathrm{Na}_{0.6} \mathrm{Zn}_{0.4}\right)$ $\mathrm{Zn}_{2}\left(\mathrm{H}_{0.6} \mathrm{AsO}_{4}\right)\left(\mathrm{AsO}_{3} \mathrm{OH}\right)_{2}$. Eur J Mineral 27: 559-573

ĐorĐević T, Karanović L, Jagličić Z (2018) A new copper(II) arsenate, $\mathrm{Na}_{2} \mathrm{Cu}_{3}\left(\mathrm{AsO}_{3} \mathrm{OH}\right)_{4} \cdot 4 \mathrm{H}_{2} \mathrm{O}$ containing discrete $\left[\mathrm{Cu}_{3} \mathrm{O}_{12}\right]^{18-}$ units: synthesis, crystal structure and magnetic properties. J Solid State Chem 265: 55-63

Drozd M, Baran J, Piatraszko A (2005) Diguanidinium hydrogen arsenate monohydrate and its deuterated analogue. Vibrational, DSC and X-ray investigations. Spectrochim Acta, Part A 61: 2809-2821

Dufresne WJ, Rufledt CJ, Marshall CP (2018) Raman spectroscopy of the eight natural carbonate minerals of calcite structure. J Raman Spectrosc 49: 1999-2007

Elliott P, Turner P, Jensen P, Kolitsch U, Pring A (2009) Description and crystal structure of nyholmite, a new mineral related to hureaulite, from Broken Hill, New South Wales, Australia. Mineral Mag 73: 723-735

Ferraris G, ABbona F (1972) The crystal structure of $\mathrm{Ca}_{5}\left(\mathrm{HAsO}_{4}\right)_{2}\left(\mathrm{AsO}_{4}\right)_{2} \cdot 4 \mathrm{H}_{2} \mathrm{O}$ (sainfeldite). Bull Soc franc Minéral Cristallogr 95: 33-41

Frost RL, Bahfenne S, Čejka J, Sejkora J, Pláššl J, PalmER SJ (2010) Raman spectroscopic study of the hydrogen-arsenate mineral pharmacolite $\mathrm{Ca}\left(\mathrm{AsO}_{3} \mathrm{OH}\right) \cdot 2 \mathrm{H}_{2} \mathrm{O}$ - implications for aquifer and sediment remediation. J Raman Spectrosc 41: 1348-1352

Hloušek J, Plášil J, SeJKora J, ŠKácha P (2014) News and new minerals from Jáchymov, Czech Republic (2003-2014). Bull mineral-petrolog Odd Nár Muz (Praha) 22: 155-181 (in Czech)

Jirásek J, Čejka J, VRtišKa L, MatÝsek D, Ruan X, Frost LR (2017) Molecular structure of the phosphate mineral koninckite - a vibrational spectroscopic study. J Geosci 62: $271-279$

KAMPF AR (2009) Miguelromeroite, the Mn analogue of sainfeldite, and redefinition of villyaellenite as an ordered intermediate in the sainfeldite-miguelromeroite series. Amer Miner 94: 1535-1540

Kampf AR, Nash BP, Dini M, Molina Donoso AA (2016) Chongite, $\mathrm{Ca}_{3} \mathrm{Mg}_{2}\left(\mathrm{AsO}_{4}\right)_{2}\left(\mathrm{AsO}_{3} \mathrm{OH}\right)_{2} \cdot 4 \mathrm{H}_{2} \mathrm{O}$, a new arsenate member of the hureaulite group from the Torrecillas mine, Iquique Province, Chile. Mineral Mag 80: 1255-1263

Keller P (1971) Die Kristallchemie der Phosphat- und Arsenatminerale unter besonderer Berücksichtigung der Kationen-Koordinationspolyeder und des Kristallwassers. Teil 1: Die Anionen der Phosphat- und Arsenatminerale. Neu Jb Mineral, Mh 491-510

LiBowitZKy E (1999) Correlation of O-H stretching frequencies and $\mathrm{O}-\mathrm{H} \cdots \mathrm{O}$ hydrogen bond lengths in minerals. Monatsh Chem 130: 1047-1059

Makreski P, Todorov J, Makrievski V, Pejov L, JovaNOVSKI G (2018) Vibrational spectra of the rare-occurring 
complex hydrogen arsenate minerals pharmacolite, picropharmacolite, and vladimirite: dominance of Raman over IR spectroscopy to discriminate arsenate and hydrogen arsenate units. J Raman Spectrosc 49: 747-763

Meisser N, Plášsil J, Brunsperger T, Lheur C, Škoda R (2019) Giftgrubeite, $\mathrm{CaMn}_{2} \mathrm{Ca}_{2}\left(\mathrm{AsO}_{4}\right)_{2}\left(\mathrm{AsO}_{3} \mathrm{OH}\right)_{2} \cdot 4 \mathrm{H}_{2} \mathrm{O}$, a new member of the hureaulite group from Sainte-Marieaux-Mines, Haut-Rhin Department, Vosges, France. J Geosci 64: 73-80

Mielke Z, RatajcZaK H (1972) The force constants and vibrational frequencies of orthoarsenates. Bull Acad Pol Sci, Sér Sci Chim 20: 265-270

Mihajlović T, Libowitzky E, EFFEnBerger H (2004) Synthesis, crystal structure, infrared and Raman spectra of $\mathrm{Sr}_{5}\left(\mathrm{As}_{2} \mathrm{O}_{7}\right)_{2}\left(\mathrm{AsO}_{3} \mathrm{OH}\right)$. J Solid State Chem 177: 3963-3970

Moore PB, Araki T (1973) Hureaulite, $\mathrm{Mn}^{2+}{ }_{5}\left(\mathrm{H}_{2} \mathrm{O}\right)_{4}\left[\mathrm{PO}_{3}(\mathrm{OH})\right]_{2}\left[\mathrm{PO}_{4}\right]_{2}$ : its atomic arrangement. Amer Miner 58: 302-307

Myneni SCB, Traina SJ, Waychunas GA, Logan TJ (1998) Vibrational spectroscopy of functional group chemistry and arsenate coordination in ettringite. Geochim Cosmochim Acta 62: 3499-3514

Naкамото K (2009) Infrared and Raman Spectra of Inorganic and Coordination Compounds. Part A - Theory and Applications in Inorganic Chemistry. John Wiley and Sons, Hoboken, New Jersey, pp 1-419

ONDRUŠ P (1993) ZDS - a computer program for analysis of X-ray powder diffraction patterns. Mater Sci Forum, 133-136, 297-300, EPDIC-2. Enchede

ONDRUŠ P, VeselovskÝ F, SKÁla R, CíSAŘová I, HLOUŠEK J, FrÝdA J, VAVŘín I, ČEJKA J, GABAŠOvÁ A (1997a) New naturally occurring phases of secondary origin from Jáchymov (Joachimsthal). J Czech Geol Soc 42: 77-107

ONdruš P, Veselovský F, HLOUŠEK J, Skála R, FrÝDA J, ČEJKA J, GABAŠOví A (1997b) Secondary minerals of the Jáchymov (Joachimsthal) ore district. J Czech Geol Soc 42: 3-76

ONDRUŠ P, Veselovský F, Gabašová A, HLOUŠEK J, ŠReIN V (2003a) Geology and hydrothermal vein system of the Jáchymov (Joachimsthal) ore district. J Czech Geol Soc 48: 3-18

ONDRUŠ P, VeselovskÝ F, GABAŠOVÁ A, DrÁBEK M, DobeŠ P, MAlÝ K, HLOUŠEK J, SEJKora J (2003b) Ore-forming processes and mineral parageneses of the Jáchymov ore district. J Czech Geol Soc 48: 157-192

ONDRuš P, VeselovsKÝ F, GABAŠOvÁ A, HLOUŠEK J, Šrein V, VaV̌rín I, Skála R, SEJKora J, DrábeK M (2003c) Primary minerals of the Jáchymov ore district. J Czech Geol Soc 48: 19-147

ONDRUŠ P, Veselovský F, GABAŠOvÁ A, HLOUŠEK J, ŠReIN V (2003d) Supplement to secondary and rock-forming minerals of the Jáchymov ore district. J Czech Geol Soc 48: 149-155

Plášil J, Fejfarová K, Hloušek J, ŠKoda R, Novák M, Sejkora J, Čejka J, Dušek M, Veselovský F, Ondruš P, Majzlan J, Mrázek Z (2013) Štěpite, $\mathrm{U}\left(\mathrm{AsO}_{3} \mathrm{OH}\right)_{2} \cdot 4 \mathrm{H}_{2} \mathrm{O}$, from Jáchymov, Czech Republic: the first natural arsenate of tetravalent uranium. Mineral Mag 77: 137-152

Pouchou J, PichoIr F (1985) "PAP" ( $\phi \rho Z)$ procedure for improved quantitative microanalysis. In: ArMSTRONG JT (ed): Microbeam Analysis. San Francisco Press, San Francisco, pp 104-106

Sejkora J, Čejka J, Frost RL, Bahfenne S, PláŠIl J, KeEFFe EC (2010) Raman spectroscopy of hydrogen-arsenate group $\left(\mathrm{AsO}_{3} \mathrm{OH}\right)$ in solid-state compounds: copper mineral phase geminite $\mathrm{Cu}\left(\mathrm{AsO}_{3} \mathrm{OH}\right) \cdot \mathrm{H}_{2} \mathrm{O}$ from different geological environments. J Raman Spectrosc 41: 1038-1043

SHANNON RD (1976) Revised effective ionic radii and systematic studies of interatomic distances in halides and chalcogenides. Acta Crystallogr A32: 751-767

Vansant FK, Van Der Veken BJ, Desseyn HO (1973) Vibrational analysis of arsenic and its anions. I. Description of the Raman spectra. J Mol Struct 15: 425-437

YuKHNEVICH GV (1973) Infrared Spectroscopy of Water. Nauka, Moscow, pp 1-208 (in Russian)

Yvon K, Jeitschko W, Parthé E (1977) Lazy Pulverix, a computer program for calculation X-ray and neutron diffraction powder patterns. J Appl Crystallogr 10: 73-74 